\title{
EFFECTS OF HEAT TREATMENT ON THE ADHESION STRENGTH, PENDULUM HARDNESS, SURFACE ROUGHNESS, COLOR AND GLOSSINESS OF Scots pine LAMINATED PARQUET WITH TWO DIFFERENT TYPES OF UV VARNISH APPLICATION
}

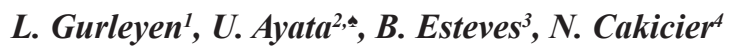

\begin{abstract}
The objective of this study was to investigate the surface properties of a UV-system applied on laminated parquet made with untreated and heat treated wood (ThermoWood). In this study, wood specimens prepared from Scots pine (Pinus sylvestris) wood were heat treated according to ThermoWood method at $190^{\circ} \mathrm{C}$ for 2 hours and at $212^{\circ} \mathrm{C}$ for 1 and 2 hours adhesion strength, pendulum hardness, surface roughness, colour and glossiness were determined. The UV-system was applied in two different types according to manufacturer recommendations. Results show that lightness and glossiness decreases and red colour tone increases with heat treatment. Pendulum hardness increased initially, decreasing afterwards with the intensity of the heat treatment. Tests showed that adhesion generally decreased with heat treatment. No significant differences were found for the surface roughness although a slight decrease was observed.
\end{abstract}

Keywords: Heat modification, lightness, Pinus sylvestris, surface properties, ThermoWood process.

\section{INTRODUCTION}

Nowadays laminate flooring is preferred over solid wood due to its dimensional stability, lower cost and similar appearance. The flooring indoors is exposed to various conditions that can change color, brightness, surface roughness and hardness of laminate flooring surface. Testing the upper surface of laminate flooring is important to give us information for its utilization. One of the most important factors in laminated parquet production is the wood species selected for the outer layer. The most widely used wood species are American red oak, white oak, beech, pine, walnut, afrormosia, merbau, maple and iroko. Each species gives laminated parquet a characteristic color, gloss, surface roughness and hardness.

Heat treatment processes have been conquering a higher market share in the last years. One of

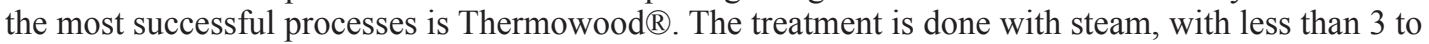
$5 \%$ oxygen without using pressure and with a minimum air speed of $10 \mathrm{~m} / \mathrm{s}$. The process begins with a rapid increase in temperature of the oven with heat and steam up to $100^{\circ} \mathrm{C}$, followed by a gradual increase up to $130^{\circ} \mathrm{C}$ to near zero humidity. Then, heat treatment is carried at temperatures between

\footnotetext{
${ }^{1}$ Yigilca Multi-Program Anatolian High School, Yigilca/Duzce, Turkey.

${ }^{2}$ Forestry and Forest Products, Oltu Vocation School, Ataturk University, Oltu/Erzurum, Turkey.

${ }^{3}$ Superior School of Technology Polytechnic Institute of Viseu, Viseu, Portugal.

${ }^{4}$ Department of Forest Industry Engineering, Duzce University, Duzce, Turkey.

"Corresponding author: umitayata@yandex.com
}

Received: 01.02.2016 Accepted: 01.03.2017 
$185^{\circ} \mathrm{C}$ and $230^{\circ} \mathrm{C}$ for 2 to 3 hours. This process is also one of the most studied processes in the last years (Korkut and Aytin 2015, Moliński et al. 2016) along with other methods as for instance those based in heat treatment and vacuum like VAP HolzSysteme ${ }^{\circledR}$ (Batista et al. 2006a,b).

Color is the most studied surface property that changes with heat treatment. It is a well-known fact that wood becomes darker and at the same time lightness decreases as reported by many authors with different wood species (Bekhta and Niemz 2003, Chen et al. 2012, Dubey et al. 2012; Esteves et al. 2007, Mitsui et al. 2001, Sundqvist 2002). In the last few years gloss changes due to heat treatment have also been studied (Aksoy et al. 2011, Bekhta et al. 2014, Karamanoglu and Akyildiz 2013).

Wettability of wood surface decreases with heat treatments as reported by several authors (Hakkou et al. 2005, Pecina and Paprzycki 1988, Pétrissans et al. 2003, Dos Santos and Goncalves 2016). In accordance to Hakkou et al. (2005), that studied the wettability change with heat treatment for poplar, pine, spruce, and beech, this change could be due to a modification of the conformational arrangement of wood biopolymers resulting from the loss of residual water or, more probably, from the plasticization of lignin. This decrease in the surface wettability slows down the absorption of glues and varnishes and consequently reduces adhesion, which means that normal finishes are usually unfit to heat-treated wood (Sernek et al. 2007). Nevertheless there are varnishes and glues that can be adapted for this type of wood.

Hardness is a very important property in flooring, especially in the outer layer, and the results reported before prove that hardness changes depends on wood species, conditions of treatment and even with the direction of the tests (Shi et al. 2007). For instance Poncsak et al. (2006) studied heattreated birch and mentioned a slight hardness increase while Korkut et al. (2008b) concluded that janka-hardness decreased with heat-treatment for Scots pine wood. Boonstra et al. (2007) reported that Brinell hardness parallel to the grain increased significantly $(48 \%)$ and hardness perpendicular to the grain increased slightly $(5 \%)$ for spruce.

Korkut and Guller (2008) studied the effects of heat treatment on the physical properties and surface roughness of red-bud maple and concluded that surface roughness decreased with increasing temperature treatment and treatment times. (Korkut et al. 2013) reported the effect of heat treatment on surface properties of wild cherry. These authors concluded that glossiness and surface roughness decreased with heat treatment compared to those of control specimens. Similar results were reported for heat treated red river gum tree (Eucalyptus camaldulensis) (Unsal and Ayrilmis 2005), black pine (Pinus nigra) (Gunduz et al. 2008) and turkish Hazel (Corylus colurna) (Korkut et al. 2008a).

The paper reports on the changes in colour $\left(\Delta E, \Delta L^{*}, \Delta a^{*}\right.$ and $\left.\Delta b^{*}\right)$, glossiness $\left(60^{\circ}\right)$ (ISO 2813 , 1994), surface roughness $\left(R_{a}, R_{y}, R_{z}\right.$ and $\left.R_{q}\right)$ (ISO 4287, 1997), surface adhesion resistance (MPa) (ASTM D 4541, 1995) and pendulum hardness (ASTM D 4366-95, 1984) of coated heat treated Scots pine laminated parquet produced in KPS company (Duzce, Turkey). 


\section{MATERIALS AND METHODS}

\section{Heat Treatment Process}

The heat treatment was performed according to ThermoWood $\AA$ process at $190^{\circ} \mathrm{C}$ for $2 \mathrm{~h}, 212^{\circ} \mathrm{C}$ for $1 \mathrm{~h}$ and $2 \mathrm{~h}$ in a private commercial Novawood Factory in Gerede - Bolu, Turkey. Heat treated and untreated wood samples were conditioned to $12 \%$ equilibrium moisture content in a special room at 20 $\pm 2^{\circ} \mathrm{C}$ and $65 \pm 5 \%$ relative humidity (ISO 554, 1976).

\section{Laminated Parquet Flooring Material}

In this study, laminated parquet flooring made with Scots pine (Pinus sylvestris L.), produced by KPS Company was selected for the tests. The production methods of laminated parquet flooring were shown in Figure 1. Five samples were prepared for each test and 6 measurements $(5 \times 6=\mathrm{A}$ total of 30 measurements) were made in each sample. The tangential surface of samples measuring $100 \mathrm{~mm}$ by $100 \mathrm{~mm}$ by $20 \mathrm{~mm}$ were used for all measurements. Wood colorant paint was used on the experimental samples. All laminated parquet flooring materials samples were conditioned to $12 \% \mathrm{MC}$ in a conditioning room at $20^{\circ} \mathrm{C}( \pm 2)$ and with $65 \%( \pm 5) \mathrm{RH}$ (ISO 554, 1976). The equilibrium MC of the samples was roughly 12 per cent after conditioning.

A43-0646 - UV sanding sealer is a type of varnish consisting of epoxy acrylic resin and ultraviolet ray curing sealers with solidity of (wt \%) $95-97$, and density of $\left(20^{\circ} \mathrm{C}, \mathrm{g} / \mathrm{cm}^{3}\right) 1: 15$ to $1: 20$. N93-0910 nanolacke UV matt varnish is a type of varnish consisting of polyacrylic-based resin, nano-containing minerals, nanocomposites ultra violet curing (UV) varnish with solidity of (wt \%) 95-100, and density of $\left(20^{\circ} \mathrm{C}, \mathrm{g} / \mathrm{cm}^{3}\right) 1: 09$ to $1: 15$. Both of these varnishes are transparent and their application field are solid hardwood, chipboard and similar types of wooden materials. 


\section{Type of Varnish Application Process}



A. Sanding (3 cylinders) \& Calibrating Machines

1. A43-0646-UV Sanding Sealer

B. UV lamp drying (mercury)

C. Sanding 2 cylinders

2. N93-0910 Nanolacke UV Matt Varnish

D. UV lamp drying

3. N93-0910 Nanolacke UV Matt Varnish

E. UV lamp drying

Polishing production line speed of $10 \mathrm{~m} / \mathrm{min}$.
80-120-220 grit sandpaper

$50 \mathrm{~g} / \mathrm{m}^{2}$

$2 \mathrm{x} 80 \mathrm{~W}$

280-320 grit sandpaper (Pressure 1,5 bar)

$7,5 \mathrm{~g} / \mathrm{m}^{2}$

$2 \mathrm{x} 80 \mathrm{~W}$

$7,5 \mathrm{~g} / \mathrm{m}^{2}$

$400 \mathrm{~W}$

\section{Type of Varnish Application Process}

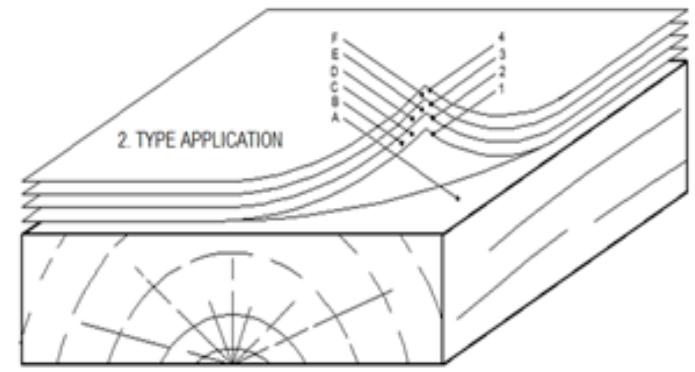
A. Sanding ( 3 cylinders) \& Calibrating
Machines

1. A43-0646-UV Sanding Sealer

B. UV lamp drying (mercury)

2. A43-0646-UV Sanding Sealer

C. UV lamp drying

D. Sanding (2 cylinders)

3. N93-0910 Nanolacke UV Matt Varnish

E. UV lamp drying

4. N93-0910 Nanolacke UV Matt Varnish

F. UV lamp drying
80-120-220 grit sandpaper

$35 \mathrm{~g} / \mathrm{m}^{2}$

$2 \times 80 \mathrm{~W}$

$35 \mathrm{~g} / \mathrm{m}^{2}$

$400 \mathrm{~W}$

280-320 grit sandpaper (Pressure 1,5 bar)

$7,5 \mathrm{~g} / \mathrm{m}^{2}$

$2 \mathrm{x} 80 \mathrm{~W}$

$7,5 \mathrm{~g} / \mathrm{m}^{2}$

$400 \mathrm{~W}$

Polishing production line speed of $10 \mathrm{~m} / \mathrm{min}$.

Figure 1. Two different types of UV varnish application process. 


\section{Glossiness and Color Measurement}

Glossiness measurements in coated wood with one and two layers were made in accordance to ISO 2813 (1994) in a Novo-Gloss Trio (Rhopoint Instruments Ltd., UK.). The measurements were made in perpendicular and parallel to the grain directions at an angle of $60^{\circ}$ (Figure 2a). The color change of laminated parquet produced from heat treated and untreated Scots pine, coated with one and two layers of finishing were analysed by a The Datacolor 110 (Wavelength resolution $10 \mathrm{~nm}$, measurement geometry D $/ 8^{\circ}$ ) with a D65 standard illuminant. Color parameters were measured using thirty replicates of each sample and an average value was reported. The CIELAB system characterized by three parameters, $\mathrm{L}^{*}, \mathrm{a}^{*}$, and $\mathrm{b}^{*}$ was used. The $\mathrm{L}^{*}$ axis represents the lightness, $+\mathrm{a}^{*}$ is the red, minus $a^{*}$ for green, $+b^{*}$ for yellow, minus $b^{*}$ for blue, and $L^{*}$ varies from 100 (white) to zero (black) (Zhang et al. 2009). Total color difference ( $\left.\Delta \mathrm{E}^{*}\right)$ was calculated using Equation 1. (Figure $2 \mathrm{~b}$ ).

$$
\Delta E^{*}=\left[\left(\Delta L^{*}\right)^{2}+\left(\Delta a^{*}\right)^{2}+\left(\Delta b^{*}\right)^{2}\right]^{1 / 2}
$$

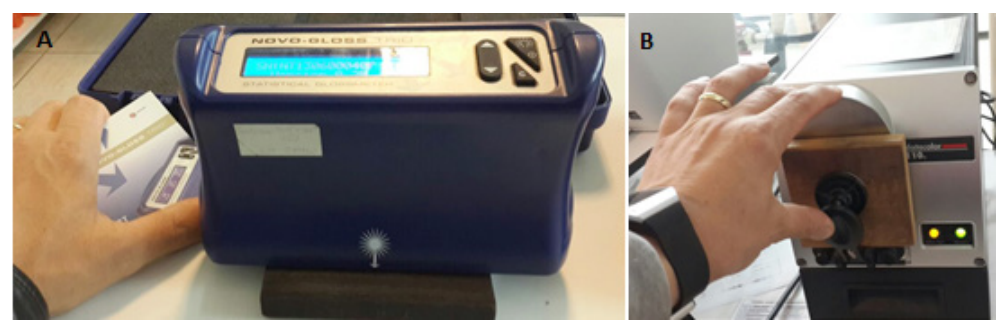

Figure 2. a) Novo-gloss trio $\left(60^{\circ}\right)$ and b) The datacolor 110 spectrophotometer.

A total of 480 data were measured for glossiness tests (Heat treatment $4 \times$ layer $2 \times$ measuring direction 2 x N 30=480 measurement). The 960 data were measured for color tests (Heat treatment 4 x layer 2 x color difference 4 x N $30=960$ measurement).

\section{Surface Roughness}

Surface roughness of all the samples was measured using a Mitutoyo Surftest SJ-301 device. Surface roughness of the samples was measured by using a stylus-type profilometer in Figure 3 (Mitutoyo 2015). In this device; $R_{a}, R y, R_{z}$ and $R_{q}$ test were measured according to ISO 4287 (1997). Four roughness parameters were determined: mean arithmetic deviation of profile $\left(R_{q}\right)$, mean peak to-valley height $\left(R_{z}\right)$, root mean square roughness $\left(R_{q}\right)$, and maximum roughness $\left(R_{y}\right)$. These parameters were commonly used in previous studies to evaluate surface characteristics of wood and wood composites such as veneer (Stumbo 1963). Roughness values were measured with a sensitivity of $0,5 \mu \mathrm{m}$. The length of scanning line $(L \mathrm{t})$ was $15 \mathrm{~mm}$ and the cut-off was $\lambda=2,5 \mathrm{~mm}$. Specification of roughness parameters is described by Hiziroglu (1996), Hiziroglu and Graham (1998). 




Figure 3. Schematic description of the mitutoyo surftest SJ-301 (Mitutoyo 2015).

A total of 960 data were measured for surface roughness tests (Heat treatment 4 x Layer $2 \mathrm{x}$ Roughness values 4 x N $30=960$ measurement).

\section{Adhesion Strength Test}

In the study, the adhesion strength was determined in accordance to ASTM D-4541 (1995) in 1 ton $(10 \mathrm{kN})$ ALSA electromechanical universal testing machine (Figure 4). 404 plastic steel epoxy strong adhesive was used (Ayata 2014). The steel test cylinders with $\varnothing 20 \mathrm{~mm}$ were attached to the sample surfaces at room temperature $\left(\sim 20^{\circ} \mathrm{C}\right)$ via the help of a cast system (Demirci et al. 2013). Glued samples were then fixed by means of tools. All sample specimens were expected to dry for 24 hours. Glue residues were removed with a cutter.

The adhesion strength $(X)$ was calculated in terms of MPa using the equation below (Budakci 2003).

$$
X=4 \mathrm{~F} / \pi \cdot \mathrm{d}^{2}
$$

Where;

$\mathrm{F}=$ the rupture force (Newton)

$\mathrm{d}=$ the diameter of the experiment cylinder (mm) (ASTM D-4541, 1995).

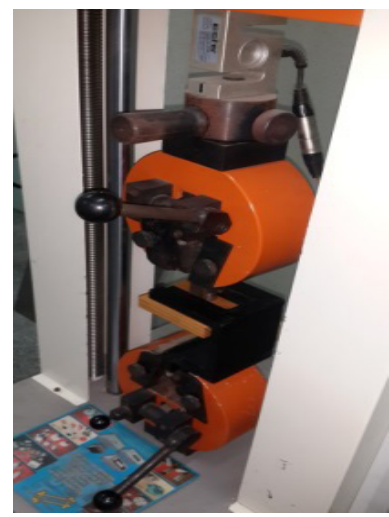

Figure 4. Adhesion test machine and test sample. 
A total of 480 data were measured for adhesion strength tests (Heat treatment 4 x Layer $2 \times \mathrm{N} 10$ $=80$ measurement).

\section{Pendulum Hardness}

Conditioned samples were subsequently subjected to the König pendulum hardness test to detect the hardness of the varnish coating according to ASTM D 4366-95 (1984). Test panels were placed on the panel table and a pendulum was gently placed on the panel surface. The pendulum was then deflected through $6^{\circ}$ and released while simultaneously starting the oscillation counter. The number of oscillations for the amplitude to decrease from $6^{\circ}$ to $3^{\circ}$ was determined to be the König hardness. Thirty replications were conducted on separate specimens for each treatment group (Figure 5) (Cakicier et al. 2011a and Cakicier at al. 2011b). Devices in the sample surface (63 $\pm 3,3$ in HRC hardness and $5 \pm$ $0,0005 \mathrm{~mm}$ in diameter) determine the hardness layer according to the oscillating pendulum swing with two balls (Ayata 2014). A total of 240 data were measured for pendulum hardness tests (Heat treatment 4 x Layer 2 x N $30=240$ measurement).



Figure 5. König pendulum hardness.

\section{Statistical Analysis}

In the experiments, statistical analysis was performed for a total of 2720 data (Glossiness $480+$ color $960+$ surface roughness $960+$ adhesion strength $80+$ pendulum hardness $240=2720$ measurement). Statistical evaluations were analyzed by IBM SPSS 17 Software Package program.

\section{RESULTS AND DISCUSSION}

\section{Color and Glossiness}

Table 1, table 2, table 3 and table 4 presents colour parameters, glossiness, pendulum hardness, adhesion strength and surface roughness parameters for untreated and heat treated wood coated with one or two layers. 
Table 1. Statistical data for color difference values in untreated and heat treated wood coated with one and two layers Scots pine.

\begin{tabular}{|c|c|c|c|c|c|c|c|c|}
\hline \multirow{2}{*}{ Heat treatment } & \multirow{2}{*}{$\begin{array}{c}\text { Layer } \\
\text { thickness }\end{array}$} & \multirow{2}{*}{$\mathrm{N}$} & \multicolumn{3}{|c|}{ Total color } & \multicolumn{3}{|c|}{ Color lightness } \\
\hline & & & Mean & $H G$ & Std. Dev. & Mean & $H G$ & Std. Dev. \\
\hline \multirow{2}{*}{ Control } & 1 coat & 30 & 85,44 & $\mathrm{~A}$ & 0,34 & 79,30 & A & 0,45 \\
\hline & 2 coats & 30 & 84,66 & $\mathrm{~B}$ & 0,10 & 78,19 & $\mathrm{~B}$ & 0,20 \\
\hline \multirow{2}{*}{$190^{\circ} \mathrm{C}-2$ hours } & 1 coat & 30 & 61,25 & $E$ & 1,32 & 48,56 & $E$ & 1,43 \\
\hline & 2 coats & 30 & 62,97 & $\mathrm{D}$ & 0,79 & 49,76 & $\mathrm{D}$ & 0,84 \\
\hline \multirow{2}{*}{$212^{\circ} \mathrm{C}-1$ hour } & 1 coat & 30 & 60,40 & $\mathrm{~F}$ & 0,50 & 47,01 & $\mathrm{~F}$ & 0,40 \\
\hline & 2 coats & 30 & 65,95 & $\mathrm{C}$ & 0,48 & 52,40 & $\mathrm{C}$ & 0,64 \\
\hline \multirow{2}{*}{$212^{\circ} \mathrm{C}-2$ hours } & 1 coat & 30 & 54,77 & $\mathrm{G}$ & 0,14 & 41,59 & $\mathrm{G}$ & 0,20 \\
\hline & 2 coats & 30 & 52,14 & $\mathrm{H}$ & 0,35 & 39,63 & $\mathrm{H}$ & 0,29 \\
\hline \multirow{2}{*}{ Heat treatment } & \multirow{2}{*}{$\begin{array}{c}\text { Layer } \\
\text { thickness }\end{array}$} & \multirow{2}{*}{$\mathrm{N}$} & \multicolumn{3}{|c|}{ Red color tone } & \multicolumn{3}{|c|}{ Yellow color tone } \\
\hline & & & Mean & $H G$ & Std. Dev. & Mean & $H G$ & Std. Dev. \\
\hline \multirow{2}{*}{ Control } & 1 coat & 30 & 2,89 & $\mathrm{H}$ & 0,22 & 31,67 & $E$ & 0,27 \\
\hline & 2 coats & 30 & 3,38 & $\mathrm{G}$ & 0,14 & 32,29 & $\mathrm{D}$ & 0,27 \\
\hline \multirow{2}{*}{$190^{\circ} \mathrm{C}-2$ hours } & 1 coat & 30 & 12,72 & E & 0,48 & 35,08 & $\mathrm{C}$ & 0,52 \\
\hline & 2 coats & 30 & 12,94 & $\mathrm{D}$ & 0,28 & 36,35 & B & 0,39 \\
\hline \multirow{2}{*}{$212^{\circ} \mathrm{C}-1$ hour } & 1 coat & 30 & 13,93 & $\mathrm{C}$ & 0,11 & 35,27 & $\mathrm{C}$ & 0,41 \\
\hline & 2 coats & 30 & 12,38 & $\mathrm{~F}$ & 0,26 & 38,08 & A & 0,17 \\
\hline \multirow{2}{*}{$212^{\circ} \mathrm{C}-2$ hours } & 1 coat & 30 & 14,73 & $\mathrm{~A}$ & 0,04 & 32,44 & $\mathrm{D}$ & 0,21 \\
\hline & 2 coats & 30 & 14,60 & B & 0,09 & 30,57 & $\mathrm{~F}$ & 0,58 \\
\hline
\end{tabular}

Table 2. Statistical data for glossiness values in untreated and heat treated wood coated with one and two layers Scots pine.

\begin{tabular}{|c|c|c|c|c|c|c|c|c|}
\hline \multirow{2}{*}{ Heat treatment } & \multirow{2}{*}{$\begin{array}{c}\text { Layer } \\
\text { thickness }\end{array}$} & \multirow{2}{*}{$\mathrm{N}$} & \multicolumn{3}{|c|}{ Glossiness perpendicular } & \multicolumn{3}{|c|}{ Glossiness parallel } \\
\hline & & & Mean & $H G$ & Std. Dev. & Mean & $H G$ & Std. Dev \\
\hline \multirow{2}{*}{ Control } & 1 coat & 30 & 17,81 & B & 0,34 & 24,66 & $\mathrm{~A}$ & 0,50 \\
\hline & 2 coats & 30 & 18,34 & $\mathrm{~A}$ & 0,46 & 25,14 & A & 0,30 \\
\hline \multirow{2}{*}{$190^{\circ} \mathrm{C}-2$ hours } & 1 coat & 30 & 17,48 & $\mathrm{BC}$ & 1,31 & 22,66 & B & 1,21 \\
\hline & 2 coats & 30 & 17,23 & $\mathrm{C}$ & 0,79 & 22,71 & $\mathrm{~B}$ & 2,83 \\
\hline \multirow{2}{*}{$212^{\circ} \mathrm{C}-1$ hour } & 1 coat & 30 & 16,64 & $\mathrm{D}$ & 0,82 & 22,45 & $\mathrm{~B}$ & 1,09 \\
\hline & 2 coats & 30 & 16,44 & $\mathrm{D}$ & 0,98 & 22,67 & $\mathrm{~B}$ & 1,94 \\
\hline \multirow{2}{*}{$212^{\circ} \mathrm{C}-2$ hours } & 1 coat & 30 & 16,25 & $\mathrm{D}$ & 1,13 & 21,77 & $\mathrm{BC}$ & 1,55 \\
\hline & 2 coats & 30 & 15,70 & $\mathrm{E}$ & 1,15 & 20,98 & $\mathrm{C}$ & 2,31 \\
\hline
\end{tabular}

In relation to color parameters, lightness decreased with the increase of the heat treatment despite the number of layers of the coating. For the less intense treatment $\left(190^{\circ} \mathrm{C}, 2\right.$ hours $)$, lightness decreased approximately $38 \%$ in relation to initial lightness and for the most intense treatment $\left(212^{\circ} \mathrm{C}, 2\right.$ hours $)$ the decrease was approximately $48 \%$. Simultaneously, red color tone increased while yellow color tone did not show any consistent change. Similar results were reported before by several authors with uncoated heat treated wood (Bekhta and Niemz, 2003; Dubey et al. 2012; Esteves et al. 2007; Mitsui et al. 2001). Glossiness, measured parallel and perpendicular to the grain decreased with the intensity of the heat treatment which is in accordance to the reported by other authors (Aksoy et al. 2011; Karamanoglu and Akyildiz 2013). There seems to be no influence on glossiness due to the coating.

\section{Pendulum Hardness, Adhesion and Surface Roughness}

Pendulum hardness increased initially, decreasing afterwards with the intensity of the heat treatment. Coating increased the hardness of the surface since pendulum hardness is higher for the samples with two coats. These results are in accordance to results presented before that stated that 
hardness changes depends on wood species, conditions of treatment and even with the direction of the tests (Shi et al. 2007). Tests showed that adhesion strength generally decreased with heat treatment, nevertheless the decrease was much smaller when two layers coating is used.

No significant differences were found for the surface roughness. Although there is no difference between $R_{a}$ parameter of treated and untreated wood, this parameter is higher for wood with two layers coating. Maximum roughness $\left(R_{y}\right)$ increases slightly with heat treatment and with the number of layers in the coating. This parameter represents the distance between peak and valley points of the profile and can be used as an indicator of the maximum defect height within the assessed profile (Mummery 1993). Similar variation was found for $R_{z}$ and somewhat for $R_{q}$ parameters. Roughness measurements by the stylus method with uncoated untreated and heat treated Turkish river red gum showed that surface roughness values decreased with increasing treatment temperature and treatment times (Unsal and Ayrilmis, 2005). Similar results were reported by (Gunduz et al. 2008) with Camiyani Black Pine (Pinus nigra), with Turkish Hazel (Corylus colurna) (Korkut et al. 2008a) and by (Korkut and Guller 2008) with red-bud maple (Acer trautvetteri Medw.).

Table 3. Statistical data for surface hardness and adhesion values in untreated and heat treated wood coated with one and two layers Scots pine.

\begin{tabular}{|l|c|c|c|c|c|c|c|c|c|}
\hline \multirow{2}{*}{ Heat treatment } & \multirow{2}{*}{ Layer thickness } & \multirow{2}{*}{$\mathrm{N}$} & \multicolumn{3}{|c|}{ Pendulum hardness } & \multicolumn{4}{|c|}{ Adhesion test (MPa) } \\
\cline { 4 - 10 } & & & Mean & $H G$ & Std. Dev. & $\mathrm{N}$ & Mean & $H G$ & Std. Dev. \\
\hline \multirow{2}{*}{ Control } & 1 coat & 30 & 43,20 & $\mathrm{D}$ & 7,237 & 10 & 1,487 & $\mathrm{AB}$ & 0,36 \\
\hline \multirow{2}{*}{$190^{\circ} \mathrm{C}-2$ hours } & 1 coats & 30 & 55,17 & $\mathrm{C}$ & 11,271 & 10 & 1,606 & $\mathrm{AB}$ & 0,61 \\
\hline & 2 coats & 30 & 69,63 & $\mathrm{~B}$ & 7,872 & 10 & 1,735 & $\mathrm{~A}$ & 0,35 \\
\hline \multirow{2}{*}{$212^{\circ} \mathrm{C}-1$ hour } & 1 coat & 30 & 44,63 & $\mathrm{D}$ & 6,184 & 10 & 0,967 & $\mathrm{D}$ & 0,18 \\
\cline { 2 - 10 } & 2 coats & 30 & 75,80 & $\mathrm{~A}$ & 8,794 & 10 & 1,365 & $\mathrm{BC}$ & 0,29 \\
\hline \multirow{2}{*}{$212^{\circ} \mathrm{C}-2$ hours } & 1 coat & 30 & 41,80 & $\mathrm{D}$ & 6,499 & 10 & 0,931 & $\mathrm{D}$ & 0,20 \\
\hline & 2 coats & 30 & 55,07 & $\mathrm{C}$ & 6,868 & 10 & 1,562 & $\mathrm{AB}$ & 0,20 \\
\hline
\end{tabular}

Table 4. Statistical data for surface roughness values in untreated and heat treated wood coated with one and two layers Scots pine.

\begin{tabular}{|c|c|c|c|c|c|c|c|c|}
\hline \multirow{2}{*}{ Heat treatment } & \multirow{2}{*}{ Layer thickness } & \multirow{2}{*}{$\mathrm{N}$} & \multicolumn{3}{|c|}{ Surface roughness $R$} & \multicolumn{3}{|c|}{ Surface roughness $R_{v}$} \\
\hline & & & Mean & $H G$ & Std. Dev. & Mean & $H G$ & Std. Dev. \\
\hline \multirow{2}{*}{ Control } & 1 coat & 30 & 1,80 & $\mathrm{~F}$ & 0,11 & 14,65 & $\mathrm{D}$ & 1,47 \\
\hline & 2 coats & 30 & 2,08 & $\mathrm{CD}$ & 0,16 & 16,15 & $\mathrm{C}$ & 2,27 \\
\hline \multirow{2}{*}{$190^{\circ} \mathrm{C}-2$ hours } & 1 coat & 30 & 2,10 & $\mathrm{C}$ & 0,12 & 17,43 & $\mathrm{C}$ & 1,97 \\
\hline & 2 coats & 30 & 2,36 & B & 0,19 & 19,23 & $\mathrm{~B}$ & 3,58 \\
\hline \multirow{2}{*}{$212^{\circ} \mathrm{C}-1$ hour } & 1 coat & 30 & 2,00 & $\mathrm{DE}$ & 0,14 & 17,22 & $\mathrm{C}$ & 1,80 \\
\hline & 2 coats & 30 & 2,48 & $\mathrm{~A}$ & 0,35 & 21,04 & $\mathrm{~A}$ & 3,18 \\
\hline \multirow{2}{*}{$212^{\circ} \mathrm{C}-2$ hours } & 1 coat & 30 & 1,97 & $\mathrm{E}$ & 0,12 & 16,73 & $\mathrm{C}$ & 1,90 \\
\hline & 2 coats & 30 & 2,17 & $\mathrm{C}$ & 0,14 & 16,88 & $\mathrm{C}$ & 2,04 \\
\hline \multirow{2}{*}{ Heat treatment } & \multirow{2}{*}{ Layer thickness } & \multirow{2}{*}{$\mathrm{N}$} & \multicolumn{3}{|c|}{ Surface roughness $R_{z}$} & \multicolumn{3}{|c|}{ Surface roughness $R_{q}$} \\
\hline & & & Mean & $H G$ & Std. Dev. & Mean & $H G$ & Std. Dev. \\
\hline \multirow{2}{*}{ Control } & 1 coat & 30 & 12,18 & $\mathrm{~F}$ & 0,71 & 2,29 & $\mathrm{~F}$ & 0,14 \\
\hline & 2 coats & 30 & 13,59 & DE & 1,44 & 2,63 & CDE & 0,23 \\
\hline \multirow{2}{*}{$190^{\circ} \mathrm{C}-2$ hours } & 1 coat & 30 & 14,28 & $\mathrm{C}$ & 1,06 & 2,67 & CD & 0,19 \\
\hline & 2 coats & 30 & 14,97 & $\mathrm{~B}$ & 1,12 & 3,00 & $\mathrm{~B}$ & 0,32 \\
\hline \multirow[b]{2}{*}{$212^{\circ} \mathrm{C}-1$ hour } & 1 coat & 30 & 14,23 & $\mathrm{CD}$ & 1,64 & 2,60 & $\mathrm{DE}$ & 0,20 \\
\hline & 2 coats & 30 & 15,97 & $\mathrm{~A}$ & 1,61 & 3,23 & $\mathrm{~A}$ & 0,47 \\
\hline \multirow{2}{*}{$212^{\circ} \mathrm{C}-2$ hours } & 1 coat & 30 & 13,42 & $\mathrm{E}$ & 1,00 & 2,53 & $\mathrm{E}$ & 0,19 \\
\hline & 2 coats & 30 & 14,02 & $\mathrm{CDE}$ & 0,94 & 2,75 & $\mathrm{C}$ & 0,16 \\
\hline
\end{tabular}




\section{CONCLUSIONS}

Overall, lightness and glossiness decreased and red colour tone increased with heat treatment and no significant differences were found between one or two layers coating. In relation to pendulum hardness there was an increase initially, decreasing afterwards with the intensity of the heat treatment. This decrease was smaller if two layers coatings are used. Although adhesion strength generally decreased with heat treatment the use of a double layer coating improved the adhesion. No significant differences were found for the surface roughness although a slight decrease was observed.

\section{ACKNOWLEDGEMENTS}

The authors would like to thank, Assoc. Prof. Dr. Suleyman Korkut for measurements of surface roughness device, ASD Laminat Factory in Duzce, Turkey for the all color and glossiness measurement, Novawood Factory, Gerede, in Bolu, Turkey for heat treating according to ThermoWood and KPS Company for laminated parquet flooring.

\section{REFERENCES}

Aksoy, A.; Deveci, M.; Baysal, E.; Toker, H. 2011. Colour and gloss changes of Scots pine after heat modification. Wood Res 56 (3): 329-336.

ASTM D 4366-95 1984. Standard test methods for hardness of organic coatings by pendulum test, ASTM, Philadelphia, PA.

ASTM D 4541 1995. Standard Test method for pull-off strength of coatings using portable adhesion testers. American Society for Testing and Materials, 12-15.

Ayata, U. 2014. Determination of The Resistance of Water Based Layers on Some Heat Treated (ThermoWood) Wood Species Against Accelerated UV Aging. Ph.D. Thesis, Duzce University, Duzce, Turkey.

Batista, D.C.; De Muñiz, B.; Ines, G.; Da Silva Oliveira, J.T.; Paes, J.B.; Nisgoski, S. 2016a. Effect of the Brazilian thermal modification process on the chemical composition of Eucalyptus grandis juvenile wood: Part 1: Cell wall polymers and extractives contents. Maderas-Cienc Tecnol 18 (2):273-284.

Batista, D.C.; De Muñiz Bolzon, G.I; Da Silva Oliveira, J.T.; Paes, J.B.; Nisgoski, S. 2016b. Effect of the Brazilian thermal modification process on the chemical composition of Eucalyptus grandis juvenile wood: Part 2: Solubility and ash content. Maderas-Cienc Tecnol 18 (2): 285-292.

Bekhta, P.; Niemz, P. 2003. Effect of high temperature on the change in color, dimensional stability and mechanical properties of spruce wood. Holzforschung 57 (5): 539-546.

Bekhta, P.; Proszyk, S.; Lis, B.; Krystofiak, T. 2014. Gloss of thermally densified alder (Alnus glutinosa Goertn.), beech (Fagus sylvatica L.), birch (Betula verrucosa Ehrh.), and pine (Pinus sylvestris L.) wood veneers. Eur J Wood and Wood Prod 72 (6): 799-808. 
Boonstra, M.J.; Van Acker, J.; Tjeerdsma, B.F.; Kegel, E.V. 2007. Strength properties of thermally modified softwoods and its relation to polymeric structural wood constituents. Ann For Sci 64: 679-690.

Budakci, M. 2003. Design and Production of a New Adhesion Testing Device and Its Utilization with Testing of Wood Varnishes. Ph.D. Thesis, Gazi University, Ankara, Turkey.

Cakicier, N.; Korkut, S.; Sevim Korkut, D.; Kurtoglu, A.; Sonmez, A. 2011a. Effects of QUV accelerated aging on surface hardness, surface roughness, glossiness, and color difference for some wood species. International Journal of the Physical Sciences (IJPS) 6 (8): 1929-1939.

Cakicier, N.; Korkut, S.; Sevim Korkut, D.; Kurtoglu, A.; Erdinler, E.S.; Ulay, G. 2011b. The effects of protective dye layer applied on varnish layer hardness, scratch resistance and glossiness of various blockboard types. African Journal of Agricultural Research 6 (10): 2303-2308.

Chen, Y.; Fan, Y.; Gao, J.; Stark, N.M. 2012. The effect of heat treatment on the chemical and color change of black locust (Robinia pseudoacacia) wood flour. BioResources 7 (1): 1157-1170.

Demirci, Z.; Sonmez, A.; Budakci, M. 2013. Effect of Thermal Ageing on the Gloss and the Adhesion Strength of the Wood Varnish Layers. BioResources 8 (2): 1852-1867.

Dos Santos, S.; Goncalves, D. 2016. Variations in wettability on heat-treated wood surfaces: Contact angles and surface free energy. Maderas-Cienc Tecnol 18 (2):383-394.

Dubey, M.K.; Pang, S.; Walker, J. 2012. Changes in chemistry, color, dimensional stability and fungal resistance of Pinus radiata D. Don wood with oil heat-treatment. Holzforschung 66 (1): 49-57.

Esteves, B.; Velez Marques, A.; Domingos, I.; Pereira, H. 2007. Heat-induced colour changes of pine (Pinus pinaster) and eucalypt (Eucalyptus globulus) wood. Wood Sci Technol 42: 369-384.

Gunduz, G.; Korkut, S.; Korkut, D.S. 2008. The effects of heat treatment on physical and technological properties and surface roughness of Camiyanı Black Pine (Pinus nigra Arn. subsp. pallasiana var. pallasiana) wood. Bioresour Technol 99 (7): 2275-2280.

Hakkou, M.; Petrissans, M.; Bakali, I.; El, Gerardin, P.; Zoulalian, A. 2005. Wettability changes and mass loss during heat treatment of wood. Holzforschung 59: 35-37.

Hiziroglu, S.; Graham, S. 1998. Effect of press closing time and target thickness on surface roughness of particleboard. Forest Prod J 48: 50-54.

Hiziroglu, S. 1996. Surface Roughness Analysis of Wood Composites: A Stylus Method. Forest Prod J 46 (7/8): 67-72.

ISO 554 1976. Standard atmospheres for conditioning and/or testing - Specifications. International Organization for Standardization (ISO), Geneva, Switzerland.

ISO 2813 1994. Paints and varnishes - Determination of specular gloss of non-metallic paint films at 20 degrees, 60 degrees and 85 degrees. International Organization for Standardization (ISO), Geneva, Switzerland.

ISO 4287 1997. Geometrical product specifications surface texture profile method terms, definitions and surface texture parameters. International Organization for Standardization (ISO), Geneva, Switzerland.

Karamanoglu, M.; Akyildiz, M.H. 2013. Colour, gloss and hardness properties of heat treated wood exposed to accelerated weathering. Pro Ligno 9 (4): 729-738.

Korkut, D. S.; Hiziroglu, S.; Aytin, A. 2013. Effect of heat treatment on surface characteristics of wild cherry wood. BioResources 8 (2): 1582-1590.

Korkut, D.S.; Guller, B. 2008. The effects of heat treatment on physical properties and surface roughness of red-bud maple (Acer trautvetteri Medw.) wood. Bioresour Technol 99: 2846-2851. 
Korkut, D.S.; Korkut, S.; Bekar, I.; Budakçi, M.; Dilik, T.; Cakicier, N. 2008a. The Effects of Heat Treatment on the Physical Properties and Surface Roughness of Turkish Hazel (Corylus colurna L.). Wood Int J Mol Sci 9: 1772-1783.

Korkut, S.; Akgul, M.; Dundar, T. 2008b. The effects of heat treatment on some technological properties of Scots pine (Pinus sylvestris L.) wood. Bioresour Technol 99 (6): 1861-1868.

Korkut, S.; Aytin, A. 2015. Evaluation of physical and mechanical properties of wild cherry wood heat-treated using the thermowood process. Maderas-Cienc Tecnol 17 (1):171-178.

Mitsui, K.; Takada, H.; Sugiyama, M.; Hasegawa, R. 2001. Changes in the properties of lightirradiated wood with heat treatment. Part 1 . Effect of treatment conditions on the change in color. Holzforschung 55 (6): 601-605.

Mitutoyo. 2015. Surface Measurement Surftest SJ-201/SJ-301 Portable Surface Testers, [online]<http://allmetech.com/images/brosuri/mitutoyo/Surftest_SJ201_SJ301_PRE\%20-\%20 rugozimetre.pdf $>[12.12 .2015]$.

Moliński, W.; Roszyk, E.; Jabloński, A.; Puszyński, J.; Cegiela, J. 2016. Mechanical parameters of thermally modified ash wood determined by compression in radial direction. Maderas-Cienc Tecnol 18 (4):577-586.

Mummery, L. 1993. Surface texture analysis. The handbook. Muhlhausen, Germany: Hommelwerke, 106 p.

Pecina, H.; Paprzycki, O. 1988. Wechselbeziehungen zwischen der Temperatur behandlung des Holzes und seiner Benetzbarkeit. Holzforsch Holzverwert 40: 5-8.

Pétrissans, M.; Gérardin, P.; Serraj, M. 2003. Wettability of heat-treated wood. Holzforschung 57: 301-307.

Poncsak, S.; Kocaefe, D.; Bouazara, M.; Pichette, A. 2006. Effect of high temperature treatment on the mechanical properties of birch (Betula papyrifera). Wood Science and Technology 40 (8): 647663.

Sernek, M.; Boonstra, M.; Pizzi, A.; Despres, A.; Gérardin, P. 2007. Bonding performance of heat treated wood with structural adhesives. Holz Als Roh - Werkst 66: 173-180.

Shi, J.L.; Kocaefe, D.; Zhang, J. 2007. Mechanical behaviour of Quebec wood species heattreated using ThermoWood process. Holz Als Roh-Werkst 65: 255-259.

Stumbo, D.A. 1963. Surface texture measurement. Forest Prod J 13 (6): 299-304.

Sundqvist, B. 2002. Color response of Scots pine (Pinus sylvestris), Norway spruce (Picea abies) and birch (Betula pubescens) subjected to heat treatment in capillary phase. Eur J Wood Wood Prod 60: $106-114$

Unsal, O.; Ayrilmis, N. 2005. Variations in compression strength and surface roughness of heattreated Turkish river red gum (Eucalyptus camaldulensis) wood. J Wood Sci 51: 405-409.

Zhang, J.; Kamdem, D.P.; Temiz, A. 2009. Weathering of copper-amine treated wood. Appl Surf Sci 256 (3): 842-846. 